\title{
Poor Thin Reservoir Horizontal Well Pattern Optimization Design
}

\author{
Zhihui Xiang \\ No.5 Production Plant of Daqing Oil Field, Daqing,163513, China \\ xzhihui@petrochina.com.cn
}

Keywords: Thin poor reservoirs; Horizontal well; Well pattern optimization; Injection-production relationship

\begin{abstract}
Aimed at the bottom of the oil field water flooding, the upper for low permeability thin poor reservoirs developed blocks. If poor vertical wells encryption mining benefit, using horizontal well development of the economic benefit is remarkable. Through the establishment of three-dimensional geological model, the optimization of horizontal well spacing advantageous area, using the numerical simulation technology, the existing vertical wells net setting of injection wells, production pressure differential and horizontal well in water injection well spacing and a half long under the condition of constant. Studied the different vertical horizontal well combination and different horizontal interval length's influence on the development effect, the simulation results show that the five mix well pattern can obtain the best development result. In five mixed well pattern on the basis of comprehensive consideration of influencing factors, such as structural reservoir drilling logging for horizontal well location and horizontal interval optimization design, through perfecting injection-production relationship, horizontal well can effectively improve the development effect of low permeability reservoirs poor results for low permeability thin reservoir development to provide a complete exploration.
\end{abstract}

\section{Introduction}

Oilfield entering high water cut development stage, unencrypted wellblock after water, at the bottom of the upper poor low permeable thin reservoir is still a large amount of remaining oil. With vertical well drilling, the economic benefit is poor difficulty of remaining bigger also using horizontal well drainage area is a big advantage in a sedimentary unit, combining with the existing vertical wells, using combined well pattern of horizontal wells and vertical wells, put forward by means of vertical wells water injection of horizontal wells and vertical wells mixed mining development train of thought [1].

Issue of wells in horizontal wells and vertical wells, many domestic and foreign scholars have done research in this field, especially in the injection-production well spacing and well pattern form has made a lot of research results [2][3], but can use of horizontal well technology to improve the effect of low permeability thin late poor reservoir development and the development benefit is a new subject a chariot north of a fault block oilfield as an example, combined with the feature of low permeability reservoir geological characteristics and development, explore the difference of low permeability thin reservoir vertical wells water injection of horizontal wells and vertical wells mixed mining mode of development, as well as the horizontal well pattern optimization design.

\section{The Geological Features of Horizontal Wells in the Study Area}

A chariot north oil field in Songliao basin in the central depression area of Daqing Changyuan secondary tectonic belt in the south of a three-stage structure, due to the effect of oil and water distribution on the vertical, not encrypt adjustment wellblock of reservoir thickness is small. North development zone one block south wellblock deployed only basic well pattern, well spacing, $450 \mathrm{~m}$, well spacing density is low, only $2.73 / \mathrm{km}^{2}$. Portuguese I4 sedimentary unit, and the following for oil-water provided or water layer, the Portuguese I1 Portuguese I3 sedimentary unit continuity of sand body development is poor, pinchout area development, only Portuguese I1 unit sheet sand body development, better continuity, the average single well developed sandstone thickness of 1.58 
m. Analysis results show that using profile layer Portuguese I1 sedimentary units remaining oil enrichment, purpose layer geological reserves of $116.6 \times 10^{4} \mathrm{t}$, economically effective excavating remaining oil potential, and puts forward the optimization of horizontal well development pattern.

Overall purpose in the study area outside layer belongs to delta front deposition environment, controlled by the north river delta sedimentary system, lakeside to delta sedimentary facies sand mud interbed is given priority to, the waves flat lay of lake, sand sheet of large-area stable distribution according to core data analysis, sheet sandstone for mud fine sandy siltstone, low permeability, air permeability (on average) $2 \mathrm{md}$, oil-bearing occurrence for the oil spot oil content is higher, accounted for $57.4 \%$,followed by oil sands oil immersion oil layer porosity is $19.5 \%$ on average, the average oil saturation is $54.59 \%$, crude oil density of $0.851 \times 10^{3} \mathrm{~kg} / \mathrm{m}^{3}$, the volume coefficient is 1.15 , for low porosity low permeability reservoir.

\section{Well Site Optimization}

WellBlock Structure Model is Established, Preliminary Determine the Cloth. Based on the results of seismic interpretation fault and breakpoints data after the vertical wellbore trajectory correction, a distribution model of the fault in three-dimensional space, fine combination of logging data and seismic interpretation horizon [4][5], well seismic joint three-dimensional structure 3D model, divided into four blocks, among them $1^{\#}$ block, $2^{\#}$ block, $4^{\#}$ block area is large and relatively flat structure, suitable for deployment of horizontal well; $3^{\#}$ block between the north and the south and adjacent faults, structural fluctuation, horizontal wells are not suitable for deployment.

Numerical Simulation Technology is used to Determine the Favorable WellBlock. In order to reduce error between wells, stochastic simulation lithology model is set up in 100 the implementation model, by using the maximum probability method in 100 on the implementation model selection, so as to get the final lithology model through to the Portuguese I1 logging interpretation results and the lithology of sedimentary unit model contrast (Table 1), that the lithology model fits well with the results of well log interpretation high precision lithology model for numerical simulation provides a good basis for simulation block area $12 \mathrm{~km}^{2}$, adopt rules center grid, select grid step $d_{\mathrm{x}}=25 \mathrm{~m}, d_{\mathrm{y}}=25 \mathrm{~m}$, longitudinal points on a layer of the numerical simulation results show that central the block $1^{\#}$ and south of the block $2^{\#}$ remaining oil enrichment suitable for deployment of horizontal wells.

Table 1 Lithology logging interpretation and model contrast

\begin{tabular}{|c|c|c|c|c|c|}
\hline category & mudstone (\%) & $\begin{array}{c}1 \text { kind of sandstone } \\
(\%)\end{array}$ & $\begin{array}{c}2 \text { kinds of } \\
\text { sandstone(\%) }\end{array}$ & $\begin{array}{c}\text { effective } \\
\text { sandstone (\%) }\end{array}$ & $\begin{array}{c}\text { sand-shale } \\
\text { ratio(\%) }\end{array}$ \\
\hline logging statistical & 36.65 & 19.75 & 11.97 & 31.63 & 63.35 \\
\hline model statistical & 40.00 & 18.22 & 15.87 & 25.86 & 60.00 \\
\hline
\end{tabular}

\section{The Horizontal Well Pattern Optimization Design}

Vertical Horizontal Well Combinations. Existing vertical wells network consists of injection wells and production wells (Figure 1), existing in the numerical simulation of vertical wells net setting of injection wells, studies the different vertical horizontal well combination effects on development effect blocks fracturing technology level of construction cost and the geological characteristics as the basis to set the parameter in the study area (Table 2), in figure 1 to 5 kinds of combinations for numerical simulation [6] [7] . 


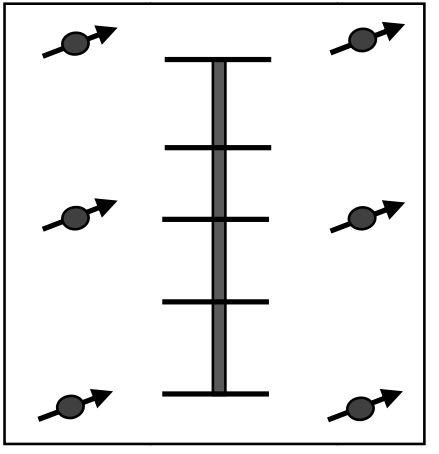

(a) The existing vertical Wells net

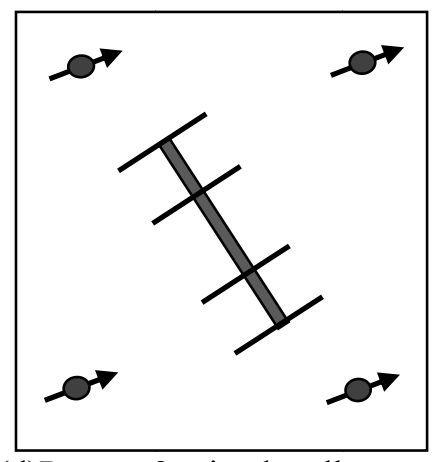

(d)Pattern 3 mixed well pattern

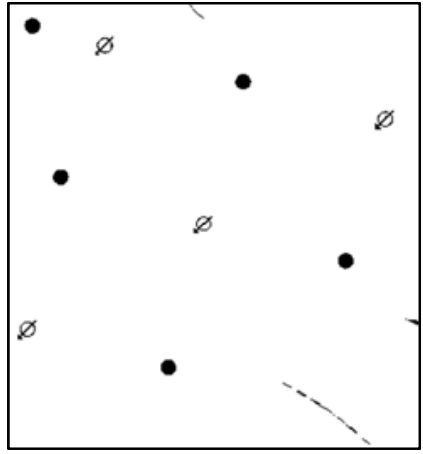

(b)Pattern 1 mixed well pattern at seven point at seven point

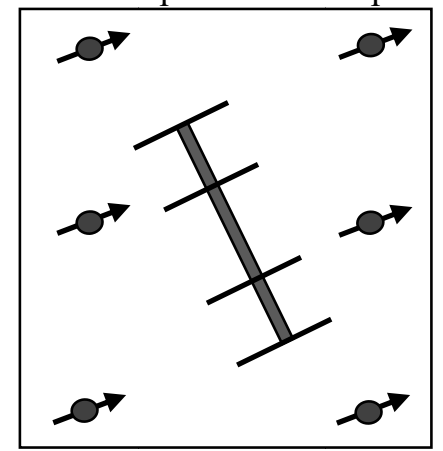

(e)Pattern 4 mixed well pattern

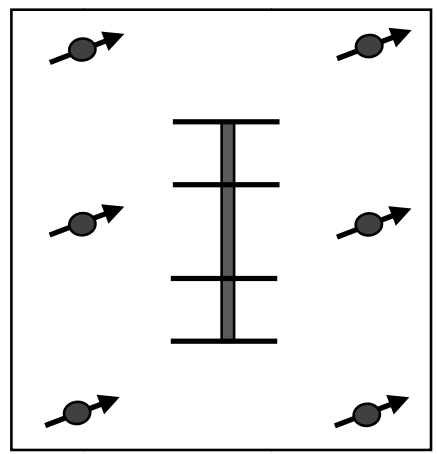

(c)Pattern2 mixed well pattern

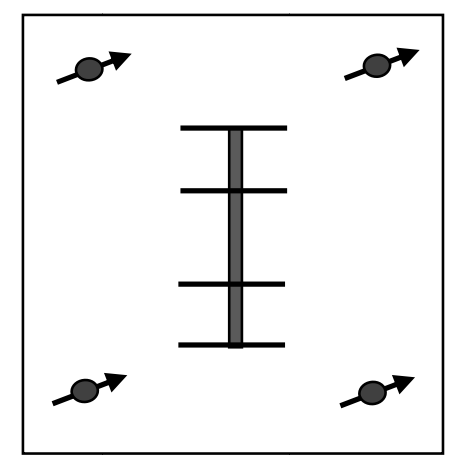

(f)Pattern 5 mixed well pattern at seven point at seven point at seven point

Figure 1 different pattern combinations

Table 2different pattern simulation parameter table

\begin{tabular}{|c|c|c|c|c|c|c|c|}
\hline $\begin{array}{c}\text { type of } \\
\text { well } \\
\text { pattern }\end{array}$ & $\begin{array}{c}\text { horizonta } \\
\text { l length } \\
(\mathrm{m})\end{array}$ & $\begin{array}{c}\text { array } \\
\text { pitch } \\
(\mathrm{m})\end{array}$ & $\begin{array}{c}\text { pattern well } \\
\text { spacing (m) }\end{array}$ & $\begin{array}{c}\text { horizontal } \\
\text { well of a } \\
\text { half long } \\
(\mathrm{m})\end{array}$ & $\begin{array}{c}\text { differential } \\
\text { pressure of } \\
\text { production } \\
(\mathrm{MPa})\end{array}$ & $\begin{array}{c}\text { porosity } \\
(\%)\end{array}$ & $\begin{array}{c}\text { air } \\
\text { permeability } \\
(\mathrm{Md})\end{array}$ \\
\hline Pattern 1 & 400 & 450 & 450 & 50 & 6 & 19.5 & 2 \\
\hline Pattern 2 & 750 & 450 & 450 & 50 & 6 & 19.5 & 2 \\
\hline Pattern 3 & 400 & 450 & 450 & 50 & 6 & 19.5 & 2 \\
\hline Pattern 4 & 400 & 450 & 450 & 50 & 6 & 19.5 & 2 \\
\hline Pattern 5 & 400 & 450 & 450 & 50 & 6 & 19.5 & 2 \\
\hline
\end{tabular}

Of injection-production well spacing 5 kinds of combinations of the simulation results shown are found.

Pattern 1 and pattern 2 for mixed well pattern, injection-production well number is higher, good energy supplement, recovery degree is higher. But the moisture content increased obviously, rapid production decline. And well pattern 2 large investment, high risk in drilling, well pattern 1 relative to the well pattern 5 occupies two horizontal well, affecting the ultimate recovery in the study area.

Pattern 3 and Pattern 4 compared with other well patterns, well pattern while the moisture content is relatively low, but the energy shortage, the early oil production and cumulative oil production effect is bad.

Mixed well pattern, well spacing for five due to the injection well spacing, horizontal section length is reasonable, can get effective displacement pressure fracture parts, so the moisture content can be effectively controlled, the production decline, slow recovery.

Horizontal Section Optimization Design. Comprehensive study of horizontal block structure 
and reservoir characteristics, combining with the logging while drilling cost and the actual use process, the five mix well spacing, drilling, using the method of vertical wells water injection design four horizontal well level wellblock relatively flat area is located in the middle of the $1^{\#}$ block structure, the area from north to south gradually thin sand body, southwest of sand.

Perfecting Injection-production Relationship between Horizontal Well. All four horizontal well design, according to the well design, early if the horizontal well production capacity is more than 6ton, you will need to consider how to improve the injection-production relationship of horizontal well, combined with vertical wells production situation, will take place around the horizontal well production focus for fluid for horizontal well. Analyzed with four vertical wells can transfer, conversion well perforated reservoir area fundamental with purpose of horizontal layer is given priority to, and now has been shut-in (Table 3), after the transfer loss reserves is relatively small. Focus after the beginning and the end of the basic form a horizontal section of left and right sides of each have 1 injection wells, the formation of the area of the 5 point well pattern, can effectively improve the development effect in the study area.

Table 3 conversion well production information table

\begin{tabular}{|c|c|c|c|c|c|c|}
\hline \multirow{2}{*}{ well number } & \multicolumn{2}{|c|}{$\begin{array}{c}\text { Perforated reservoir } \\
\text { thickness(m) }\end{array}$} & \multicolumn{2}{|c|}{$\begin{array}{c}\text { thickness of target } \\
\text { strata }(\mathrm{m})\end{array}$} & \begin{tabular}{c} 
The cumulative \\
oil production \\
\cline { 2 - 5 }$\left(\times 10^{4} \mathrm{t}\right)$
\end{tabular} & $\begin{array}{c}\text { current production } \\
\text { situation }\end{array}$ \\
\cline { 2 - 5 } Sandstone & valid & sandstone & valid & low pressure low yield \\
North 12 & 1.7 & 0.9 & 1.2 & 0.9 & 0.1941 & shut-in \\
\hline North 14 & 4.1 & 2.2 & 2.8 & 1.6 & 0.495 & bailing shut-in \\
\hline North 16 & 2.6 & 1.5 & 2.4 & 1.5 & 2.5831 & bailing shut-in \\
\hline North 17 & 1.6 & 1.6 & 1.9 & 1.9 & 0.0999 & planned shut-in \\
\hline average single well & 2.5 & 1.6 & 2.1 & 1.5 & 0.8430 & \\
\hline
\end{tabular}

\section{Conclusion}

Using horizontal well drilling, the determinant of vertical wells water injection well pattern can maximize the use of the layers of reserves, effective development of sandstone thickness below $1.5 \mathrm{~m}$, porosity is less than $20 \%$ of the poor thin layers. In order to ensure the development of horizontal well in low permeability thin reservoir benefit, need to consider structure and sand body distribution, existing well pattern and drilling process and vertical wells capacity factors for well pattern optimization design. Has been developed for low permeability thin poor reservoir area of well pattern, considering the production cost, selecting appropriate way of injection-production well spacing types and reasonable deployment pattern, can significantly improve late of low permeability reservoir development effect.

\section{Reference}

[1] Wenrui Hu. Reservoir engineering design of horizontal well [M]. Beijing: petroleum industry press, 2005.

[2] Susan wang, XuebaoYang, etc. The peripheral oil fields of daqing have a fine reservoir description technology research [J]. Journal of oil, 2006, 27 (suppl):107-109.

[3] Xianwen Zhou, etc. Low abundance in the peripheral part of daqing low permeable thin reservoir horizontal well development technology [J]. Journal of Inner Mongolia, petrochemical industry, 2008, (7): 83-84.

[4] Yong Yang, Gongwen Li, QiYouRan. Stochastic modeling technique application in reservoir evaluation, oil and gas geological corpus (9) [M]. Beijing: geological publishing house, 1999.2028.

[5] DianxingRen,Fan-hua Li, Baozhu Li. What conditions of reservoir geological modeling technology [J]. Journal of petroleum exploration and development, 2008, 35 (2):205-214. 
[6] Xinquan Ran, Qigui Chen, XueFengQu, etc.Of low permeability sandstone reservoir with horizontal well pattern form study [J]. Journal of oil, 2008, 29 (1):89-91.

[7]ZongFaLing, Lijuan wang, Yongle Hu, etc. Horizontal well reasonable injection-production well pattern well spacing and injection rate optimization $[\mathrm{J}]$. Journal of petroleum exploration and development, 2008, 35 (1):85-91. 